\title{
Enset (Enset ventricosum (Welw.) Cheesman) Breeding for Various Purposes - A Review
}

\author{
Getachew Etana Gemechu ${ }^{1}$, Samrawit Silas Simmon ${ }^{2}$ \& Efrem Asfaw ${ }^{3}$ \\ ${ }^{1}$ Associate Researcher of Horticultural crops, Jimma Agricultural Research center, EIAR, Ethiopia \\ ${ }^{2}$ Assistant Researcher I of horticultural crops, Jimma Agricultural Research center, EIAR, Ethiopia \\ ${ }^{3}$ Associate Researcher of Agricultural Economics, Jimma Agricultural Research center, EIAR, Ethiopia \\ Correspondence: Getachew Etana Gemechu, Horticultural crops, Jimma Agricultural Research center, EIAR, \\ Ethiopia. E-mail: getuetana2006@gmail.com
}

Received: June 19, 2021

Accepted: September 8, $2021 \quad$ Online Published: September 10, 2021

doi:10.5539/jps.v10n2p39

URL: https://doi.org/10.5539/jps.v10n2p39

\begin{abstract}
Enset (Enset ventricosum (Welw) Cheesman) is a well-known cultivated crop in Ethiopia and a cultural staple food for over 20 million humans in different parts of Ethiopia. It bears flowers that developed into fruits and seeds. It bears seeds and propagated vegetativly. Attempts have been done for maintenance, conservation, improving cultivars, diversity, and variability study. About 623 Enset germplasm were collected from 12 main growing areas and ex-situ conserved at Areka. Seeds of Enset were stored at the millennium gene bank. Seedlings and specimens are held in the garden of Cambridge Cottage and Wakehurst. In the research effort 6 cultivars: 3 early set cultivars: Yanbulle, Gewada, Endale, and 3 late set cultivars: Kelisa, Zerita, Mesena were released. Variability study revealed that corn yields were significantly affected by location, cultivar, and cultivar Vs location. Genotypes: Suite, Warke, Bidu, Astera, and Kekari showed 100\% disease symptoms after 30 days of inoculation. Symptoms weren't observed on Meziya, Bedadet, Hiniba, and Nech Enset clones after 90 days of inoculation. ISSRs primers revealed that, in all parameters, Kefficho genotypes have been more diversified than genotypes from Essera areas. The Partitioning of Shannon's diversity index indicated that the major variations were occurred within populations than between the two populations.
\end{abstract}

Keywords: breeding, cultivar, diversity, variability, resistant

\section{Introduction}

Enset (Enset ventricosum (Welw.) Cheesman) is a perennial, herbaceous, and monocarpic, crop, belonging to the family Musaceae and the genus Enset. According to Birmeta et al., (2004), enset is a diploid plant with the haploid chromosome number $\mathrm{n}=9$. It is well-known as the "false banana" for its more resemblance to the domesticated banana crop. Among 25 species of Enset equivalently distributed to Asia and Africa (Karlsson et al., 2013); Enset ventricosum (Welw.) Cheesman is widely cultivated in Ethiopia. It is a cultural staple food crop for over 20 million people in the South and south-west parts of Ethiopia. It has been estimated that about 146,000.00 hectares of land in Southern Nations, Nationalities and Peoples Regional State (SNNPRS) and $79,000.00$ hectares of land in Oromia has been cultivated. It has been grown in a wide range of altitude with the best favourable elevation between 2000 and $2750 \mathrm{~m}$. a. s. 1 for cultivation having a mean annual rain fall range of 1100 to $1500 \mathrm{~mm}$ (Yemataw et al., 2016). The plant can with stand a relatively long lasting of dry season for about 5 months. The mean temperature for its growing areas is between 10 and $21^{\circ} \mathrm{C}$ and relative humidity of 63 to $80 \%$ with favorable soil of moderately acidic to alkaline (pH of 5.6 to 7.3). Enset grown best in most of the soil types which are fertile enough and well-drained. It prefers Nitisol to vertisol (Yeshtila et al., 2011). Enset bears flowers that resemble banana flowers. As the flower stalk grew, it took on an arched appearance. The flowers are produced in conspicuous 2-3m long inflorescences' which are directly at the apex of each pseudostem. About $4 \mathrm{~cm}-8.5 \mathrm{~cm}$ long white to cream coloured flowers are bisexual or male, and occasionally also female(http://www.cooltropicalplants.com). There are usually 15-25 too hard, black seeds per fruit. They also bears vary from $0-40$. The seeds are presented in an edible but tasteless orange pulp and vary in size $(1.2-2.3 \times 1.2 \times 1.8 \times 0.9-1.6 \mathrm{~cm})$. They also vary in shape from nearly spherical to flattened and irregular hard, and from deeply striate (grooved) to almost smooth (http://www.kew.org/science conservation). Enset is traditionally propagated by vegetative, and plants are harvested before the seed set. There is a request for new cultivars and 
traits that could be improved by conventional breeding through seeds and selection (Karlsson et al., 2013). Enset ventricosum does not spontaneously produce suckers like banana and is not grown for its fruits. There are several hundred landraces (clones), having different characteristics and uses (food, fodder, fiber, traditional medicine) (Yemataw et al., 2014b). There is a demand for new and improved cultivars of Enset, including increased tolerance to diseases and environmental constraints as drought and frost. To make selection possible, there must be genetic variation; this can be achieved by using seeds for propagation (Tobiaw \& Bekele, 2011). Conventional breeding is a nearly endless possibility of gene recombination achieved by seed set and thereafter selecting suitable plants for different purposes can be very successful. Several attempts were /have been done conventionally to maintain, conserve, and develop variety and diversity or variability study (Karlsson et al., 2013). An attempt was done to screen clone resistance to bacterial wilt disease which is the most important disease affecting enset yield and quality (Hunduma et al., 2015). In the classic plant breeding method of Enset, some sort of information has been forwarded in the use of inter simple sequence repeats (ISSRs) as molecular marker and SSR markers for genetic divergence identification analysis in Ethiopia (Olango et al., 2014). So the objective of this paper is: To review the status of genetics and breading method of Enset crops.

\section{Enset Genetics and Breeding}

\subsection{The Flower Biology of Enset}

Enset bears flowers that resemble banana flowers. On closer inspection, the plant had begun to produce something resembling a corn on the cob. As the flower stalk grew, it took on an arched appearance. The sepal-like bracts surrounding the 'bell' as it is known opened up to reveal the flowers within. These flowers were particularly alluring for all flying insects of the brown and yellow striped variety but in particular wasps. The flowers are produced in conspicuous 2-3 m long inflorescences which are borne directly at the apex of each pseudostem. The $4 \mathrm{~cm}-8.5 \mathrm{~cm}$ long, white to cream-colored flower is bisexual (female or male). In Bisexual female flowers are found at the base of the inflorescence whereas male flowers are produced near to the apex. The floral display is supported by large maroon-purple bracts subtending large groups 'hands' of flowers. The yellow or orange-colored fruits are $8-15 \mathrm{~cm}$ long and up to $4-5 \mathrm{~cm}$ in diameter, usually with a persistent style and floral remains. Although the bracts were initially held wide open, as the stem continued to grow, the older bracts withered and cloaked the subsequent (http://www.cooltropicalplants.com).

\subsection{The Seed Biology of Enset}

There are usually 15-25 very hard, black seeds per fruit, although numbers vary from 0-40. The seeds are embedded in an edible but tasteless orange pulp and vary in size $(1.2-2.3 \times 1.2-1.8 \times 0.9-1.6 \mathrm{~cm})$. They vary in shape from nearly spherical to flatten and irregular, and from deeply striate (grooved) to almost smooth (Fig 1) (http://www.kew.org/science conservation). The germination of Enset Ventricosum seeds is not an exact science. There were many theories stated around as to what is the best technique. The freshness of the seeds would appear to be more important than other factors. Two reliable methods to germinate your seeds are germinating seeds in pots and using the Baggie method. The germination of the Enset Ventricosum is somewhat erratic. It cannot depend upon plants germinating this year for the current garden plan. Growing Abyssinian bananas in succession and therefore knowing what we have in stock makes planning your garden easier (http://www.cooltropicalplants.com).
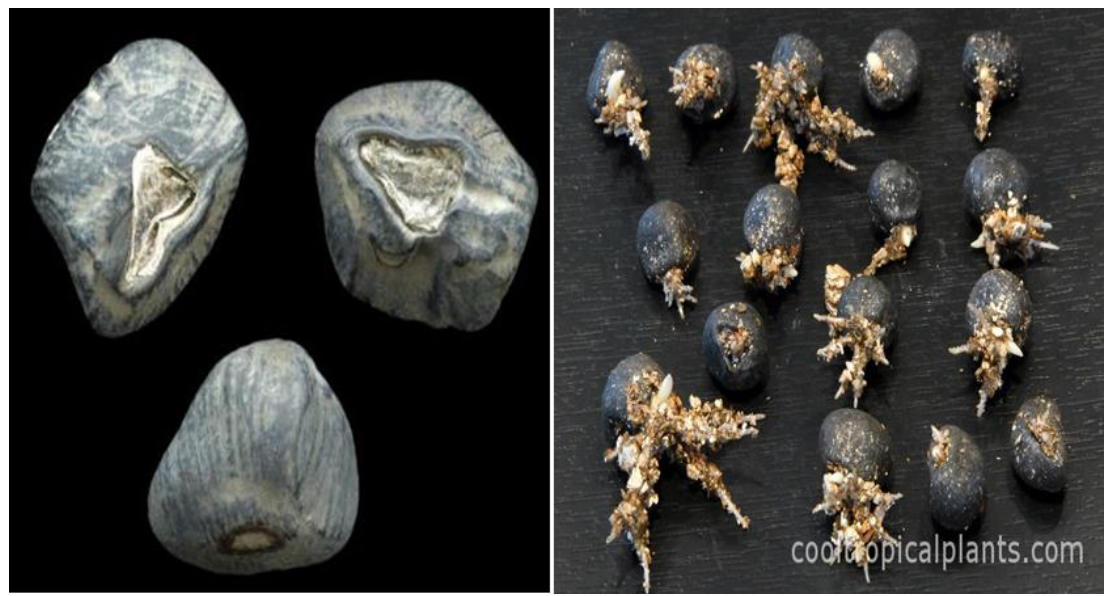

Figure 1. The Seed Biology of Enset

Source: (http://www.cooltropicalplants.com) 


\subsection{Vegetative Propagation of Enset}

The vegetative growth habit of Enset is similar to banana plants, but Enset ventricosum does not spontaneously produce suckers and as is not grown for the fruits. These fruits contain mostly large and very hard seeds and plants are usually harvested at the onset of flowering (Karlsson et al., 2011). The main reason why Enset is not producing sucker like banana is that due to the presence of flower stalk and hence has been cut off, the plant will begin to form suckers from the base (http://www.cooltropicalplants.com). As in other bananas, the main pseudostem dies after flowering and fruiting. However, unlike other bananas, enset rarely produces suckers unless the plants are intentionally induced to do so for vegetative propagation. Depending on the clone (or cultivar) and environmental conditions, flowering occurs after about four to eight years. Enset seedlings can be used in research for the selection of new cultivars with desired traits with additional characteristics to investigate pollination requirements, fertilization mechanisms, and environmental conditions affecting seed sets (Karlsson $e t$ al., 2013). Seedlings can be used in addition to the genetic engineering suggested, as it's not always possible to find one or a few genes that allow the development of the desired clone and conventional breeding does not require any expensive or sophisticated equipment. With the random recombination of the entire genome, which is the result of natural sexual reproduction with seeds, the number of combinations of genes, and thus expressed characteristics is nearly endless. This is shown also in taro (Colocasia esculenta), a corn crop grown in Ethiopia (Beyene, 2013). The recombination of genes in seeds, the reason for breeding and selection, may result in unsuitable plants for the intended purpose. Breeding should be performed in controlled ways, following the variety release procedure (Karlsson et al., 2013).

\subsection{Achievements in Genetics and Breeding of Enset Plant}

Even though; the start of breeding was by nature, human beings interfere with breeding for the search of necessities. Population increase, human need increases in turn increase from time to time. To fulfill these needs human being attempts to breed high yield, disease-resistant, and environmentally adaptable Enset crops through a convectional and modern way of breeding.

\subsubsection{Enset Germplasm Conservation for Further Breeding and Use}

In Ethiopia, despite most of the genetic diversity of Enset has been conserved traditionally in situ by farmers. Many useful clones have been lost which inhibits the diversity and variability of the crops. By now valuable attempts have been made by Areka agricultural research center and a total of 623 Enset germplasm were collected from 12 major growing area of enset in Ethiopia and ex-situ conserved at Areka southern regional research center (Table.1) (Yeshtila et al., 2011).

Table 1. Collected and ex-situ conserved enset germplasm at Areka National research center

\begin{tabular}{lllllllll}
\hline No & $\begin{array}{l}\text { Area of } \\
\text { collection }\end{array}$ & $\begin{array}{l}\text { No clones } \\
\text { Collected }\end{array}$ & No & $\begin{array}{l}\text { Area of } \\
\text { collection }\end{array}$ & $\begin{array}{l}\text { No clones } \\
\text { collected }\end{array}$ & No & $\begin{array}{l}\text { Area of } \\
\text { collection }\end{array}$ & $\begin{array}{l}\text { No clones } \\
\text { collected }\end{array}$ \\
\hline 1 & Kambata/Hadiya & 94 & 5 & Sidamo & 49 & 9 & East Shewa & 27 \\
2 & Dawaro/Waka & 93 & 6 & Guragie & 44 & 10 & Kaffa & 29 \\
3 & Gamo/Gofa & 71 & 7 & Yem & 49 & 11 & Shaka & 57 \\
4 & Wolayta & 43 & 8 & Wand SW shewa & 35 & 12 & Jimma & 32 \\
\hline
\end{tabular}

Source: (Yeshtila et al., 2011).

Agene bank which is a world conservatory Kew's millennium seed bank partnership aims to save plant life worldwide, focusing on plants under threat and those of most uses in the future Seeds are dried, packaged, and stored at a sub-zero temperature. About 1,145 seeds of Enset were collected and stored at this millennium gene bank. The characters of the seed are orthodox type and are therefore amendable to long lasting frozen storage. In seedling form and its specimens have been are held in the behind the scenes of tropical nursery, Cambridge cottage garden and the orange room at Wakehurst. Pressed and dried specimens were held in the Herbarium, one of the behind-the-scenes areas of Kew. The details, including images, of some of these, can be seen online in the Herbarium Catalogue (http://www.kew.org/science conservation).

\subsubsection{Development of Enset Varieties}

Interesting goals were achieved in Enset breeding and development of varieties for the best quality and yield of Koch. The trial was conducted on 400 Enset accessions collected from the main Enset growing zone (Kambata, Dawaro, Gamo Gofa, Wolayita, Sidama, and Gurage) of the SNNP region of Ethiopia. The accessions were characterized, evaluated, and maintained at Areka agricultural research center. Since 2006, from evaluated 
accessions; 9 promising accessions were verified on the station of five (5) different agricultural research centers (Areka, Holleta, Jimma, Kulumsa and Awada sub-center) having different agro-ecology and on-farm of six (6) farmers' fields at Wenago, Chichu, and Areka. The trial has resulted in the release of six (6) varieties of Enset through the ministry of agriculture and evaluation committee named as early set varieties and late set varieties which were the first in Ethiopia as well as in the world (Table 2) (Yeshtila et al., 2012).

Table 2. Recently released Enset varieties by Areka Agricultural research center

\begin{tabular}{|c|c|c|c|c|c|c|c|c|c|}
\hline \multirow[t]{2}{*}{ Yield } & & \multicolumn{4}{|c|}{ Early set varieties(year of release) } & \multicolumn{4}{|c|}{ late set varieties (year of release) } \\
\hline & & Yanbulle & Gewada & Endale & $\begin{array}{l}\text { Local } \\
\text { Check } 1\end{array}$ & Kelisa & zerita & Mesena & $\begin{array}{l}\text { Local } \\
\text { check } 2\end{array}$ \\
\hline Un squeezed & On station & 31.49 & 22.75 & 26.16 & 14.18 & 23.13 & 24.58 & 19.81 & 10.10 \\
\hline $\begin{array}{l}\text { Kocho ton } \\
\mathrm{ha}^{-1} \mathrm{y}^{-1}\end{array}$ & Farmers field & 18.96 & 17.17 & 17.77 & 9.38 & 17.15 & 19.01 & 18.59 & 8.33 \\
\hline Squeezed & On station & 21.12 & 15.13 & 17.47 & 9.26 & 15.39 & 16.39 & 13.12 & 6.47 \\
\hline $\begin{array}{l}\text { Kocho ton } \\
\mathrm{ha}^{-1} \mathrm{y}^{-1}\end{array}$ & Farmers field & 12.54 & 11.31 & 11.72 & 5.98 & 11.30 & 12.57 & 12.28 & 5.26 \\
\hline
\end{tabular}

Source: (Yeshtila et al., 2012).

Currently, different accessions which are selected for their high yield and disease resistance have been under evaluation and verification on Jimma, Bonga, and Areka research centers and on farmer fields to release after registration as a variety.

\subsubsection{Enset Genetic Variability and Diversity Studies}

Ethiopian highlands are the center of origin for enset. Nowadays, a crop is highly diversified across the country. Numerous enset landraces differ concerning morphological structure and character (leaf, midrib, petiole, and pseudostem colour), valuable parts like kocho, corm, and fiber), qualitative product and maturity duration, crop stand vigor, and reaction to bacterial wilt (Tsegaye and Struik, 2002; Jarvis et al., 2008). Trials were conducted in two locations of Southern Ethiopia at Areka and Chichu in 2012-2013 Enset cropping season for the study of genetic variability across and to recommend best accessions (Yemataw et al., 2016). A total of 35 cultivars were collected from different parts of the country by Areka Agricultural research. From Kembata-tembaro(Sebera, witea, Tessa, Qoyina, Bose, Nekaka, Bino), Wolaita (Sirareia, Neqaqa, Shelequmia, Silqantia), Gamo Goffa (Haleko, Matiya, Keteniya, Gena, Tuffa, Zinka), Gurage (Astara, Chohot, Qibnar Ashakit, Gazner, Fenqo, Agade), Gededo (Niffo), Sidama(Addo, Gedeme) and Dawaro (Diqa, Musula, Bukuniya, Neqaqa, Switeia, Argema, Arkiya).The combined analysis of variance over the experimental locations resulted in Enset corm yield was significantly affected by location, which is a proxy for the environment $(\mathrm{E})$, cultivar, which is a proxy for genotypes $(\mathrm{G})$, and cultivar $\mathrm{x}$ location interactions. The significance of the interaction indicated the best cultivars in one location (hence environment) are not necessarily the best in another (Yemataw et al., 2016). Genotypes differ significantly in their mean yield performance. The genotypes: Chohot, Ashakit, Bose, and Ganezer had the highest values for corm yield ha ${ }^{-1}$ year $^{-1}$. Hence, cultivars that were grouped in high and medium yielding were found to be promising for corm yield. For selection, good performance is not sufficient; the cultivar must also have desirable sensory and utilization characteristics. Ashakit and kataniya were the most preferred cultivars with all test attributes having good scores whereas the first best performing cultivar (Chohot) was among the least preferred genotypes with a low score (Yemataw et al., 2016).

Tsegaye (2002) identified enset clones from three zones; 52 clones from Sidama, 55 clones from Wolayita, and 59 clones from Hadiya. Moreover, Tesfaye and Ludders (2003) reported 86 enset clones in the south and southwestern part of Ethiopia. Olango et al. (2014) surveyed the Wolaita zone and recorded 67 enset clones; of which 31 clones from lowland and 52 clones from the high and mid-land area. Yemataw et al., (2014) identified 218 enset diversities in eight zones of SNNP. Zeberga et al. (2014) identified 312 enset clones from eight zones in southern Ethiopia. Assefa and Fitamo (2016) recorded 61 enset clones in Sidama Zone, Southern Ethiopia. Recently, Semman et al., (2017) reported names of 99 enset clones in the Sheka zone southwestern Ethiopia, and the clones were varied ranging from 2 to more than 50 clones in each Kebele. Zerfu et al. (2018) recorded 93 enset clones based on farmers' indigenous knowledge of identification from the sampled ten kebeles found in yem special woreda.

\subsubsection{Farmers Participatory Enset Genetic Variability and Diversity Studies}

Landrace diversity on the enset was numerous. Negash (2001) reported that farmers maintain and enrich the 
diversity of enset and select or classify clones for various uses. With the participation farmer's selection criteria, a survey was done in Wolaita "enset" culture community. Different methods were used like Précised ethno botanical information of intra-specific diversity of enset Ethno-botanical information of intra-specific Enset diversity and local knowledge on how the villages or community manage and benefited from the enset genetic resources. Genetic resources are important for the promotion, conservation, and improvement of the in the farming system. The study sample composed of 270 households from 12 kebeles was done which is the representative of three major different agro-ecological zones. Its associated folk folk-iosystematics, food culture, and material were also studied. In the study, about 67 enset land races were known and recorded. They were identified using 11 descriptors mainly related morpho-agronomic traits and coocking quality which are named after perceived places of origin. The folk classification of enset is based on domestication condition, gender, ecological adaptation, and land race use for different food and others (feed, fiber, and medicine). In Wolaita about 10 different food dishes, 8 of which are mainly used for their consumption ranges from daily staple to specific food in festival occasion and ceremonies. The land race divergence and richness have been guided by house hold needs; their dynamics have been managed through reproduction, harvest restrains, land race composition and design arrangements in home gardens. The information is crucial for developing community-based complementary in situ and ex situ conservation strategies to foster conservation of Enset genetic resources and associated indigenous knowledge systems.

\subsubsection{Selections of Disease Resistance Enset Clones through Conventional Breeding Methods}

Enset is one of the great important staple and co-staple of food crops for about 20 million human beings in Ethiopia. The production of this crop has been treated by a very devastating diseases called bacterial wilt which is caused by Xanthomonas campestris pv. musacearum. This disease was officially reported and announced in Ethiopia by the time of 1960's for the first. To screen resistance accessions to the disease, twenty enset accessions were assessed and collected from different district of Oromia regional state. From Tikur Inchini district (Warqee Ija, Hadha Bishan, Hadha Bala, Bedadet, Sabara, Warke Bidu, Hiniba, Kekar, Astera, Warke Adi, Awegene, Warke Dima, Garda Dhera, Shartiye, Awenyi; from Jibat (Garda Gababa, Ferasiye, Abba Jobir ) and from SPNN region: Areka (Suite, Meziya ) which are located between an altitude range of 2102-2582 m. a. s. 1 . They were screened for resistance/tolerance to the disease through artificial inoculations. The clones of enset: Suite, Warke, Bidu, Astera, and Kekari showed 100\% symptoms of disease after 30 days of inoculation and therefore, may it be used as susceptible checks in future screening trials of enset. The symptoms of the disease did not observed on clones: Meziya, Bedadet, Hiniba, and Nech enset 90 days after inoculations durations. These were relative as resistance to the target wilt causing Pathogen in Enset. About 20 enset clones were evaluated for resistance/tolerance to $\mathrm{Xcm}$ by artificial inoculation under pot culture condtion. Among the evaluated Meziya clone was found to have the lowest percentage of disease incidence with $19.31 \%$ followed by Hiniba with $30.18 \%$ and Bedadet with 34.26 clones. The clones "Meziya", "Hiniba", "Bedadet" and "Warke Dima" were resulted in better resistance/tolerance against the wilt disease. As a result these clones could be considered as the most tolerant clones to the pathogen and the clones can be used as the bacterial wilt management. The clones "Warke Bidu", "Awenyi", and "Kekar" showed 100\% disease symptoms after 30 days of inoculation. As a result they used as susceptible checks in the future breeding and screening programs. Over all the, the enset clones vary in reaction bacterial wilt disease (Hunduma et al., 2015).

Haile et al., (2020) conducted trial to determine the pathogenicity of $\mathrm{Xcm}$ isolates to select resistance/tolerant enset clones. About $30 \mathrm{Xcm}$ isolates were subjected to pathogenicity test on susceptible enset clones called Yeko. Result revealed that all were founded pathogenic. The incidence recorded was ranged from $0-90 \%$ and IP ranged from 0-23 days. In line with this, the days to completely wilted susceptible clones reached up to 63 days. The calculated AUDPC values were zero for Gudiro, Maziya, and Nobo and ranged to 31-90 days for Arkia, Ataro, Yeko, Chikaro, and Ogisso. The disease progress rates also ranged from -0.00165-0.04398 units day ${ }^{-1}$. Under this experiment clones Gudiro, Maziya, and Nobo resulted in resistant /tolerant to the wilt disease meanwhile clones Arkia, Yeko, Ataro, Chikaro, and Ogisso were resulted as the most susceptible clones. Similarly, disease progress curves (severity versus DAI) sketched from PSI data showed differences for each enset clone and Xcm isolate combinations. The disease progress curves in Figure 2 depicted that, only for the combinations of four enset clones (Chikaro, Gudiro, Barasho, and Nobo) and the three Xcm isolates which were sketched based on EBW severity levels compared with susceptible and tolerant clones. The disease severity in enset clone Chikaro resulted in a highly raised progressive curve and showed the highest level of PSI. The disease progressive curve of Nobo enset clone resulted in none progression and lied on $\mathrm{X}$-axis for each isolate combinations. The disease progressive Curve of enset clones Gudiro x Xcm isolates progressed slowly and decreased rapidly and declined to the $\mathrm{X}$-axis in response to recovery of infestation late in the epidemic period (Haile et al., 2020). 
Haile et al., (2020) reported that, even though all of the $\mathrm{Xcm}$ isolate are pathogenic to most of the agro-ecologically adapted enset clones in South-west Ethiopia, some accessions like Gudiro, Maziya, and Nobo were showed better resistance reaction to enset bacterial wilt. Therefore Gudiro and Nobo should be considered as resistant clones to the Pathogen wilt and recommended for farther bacterial wilt management systems. From the promising result, resistant/tolerant genetic materials from enset growing regions of South-west Ethiopia could be developed.

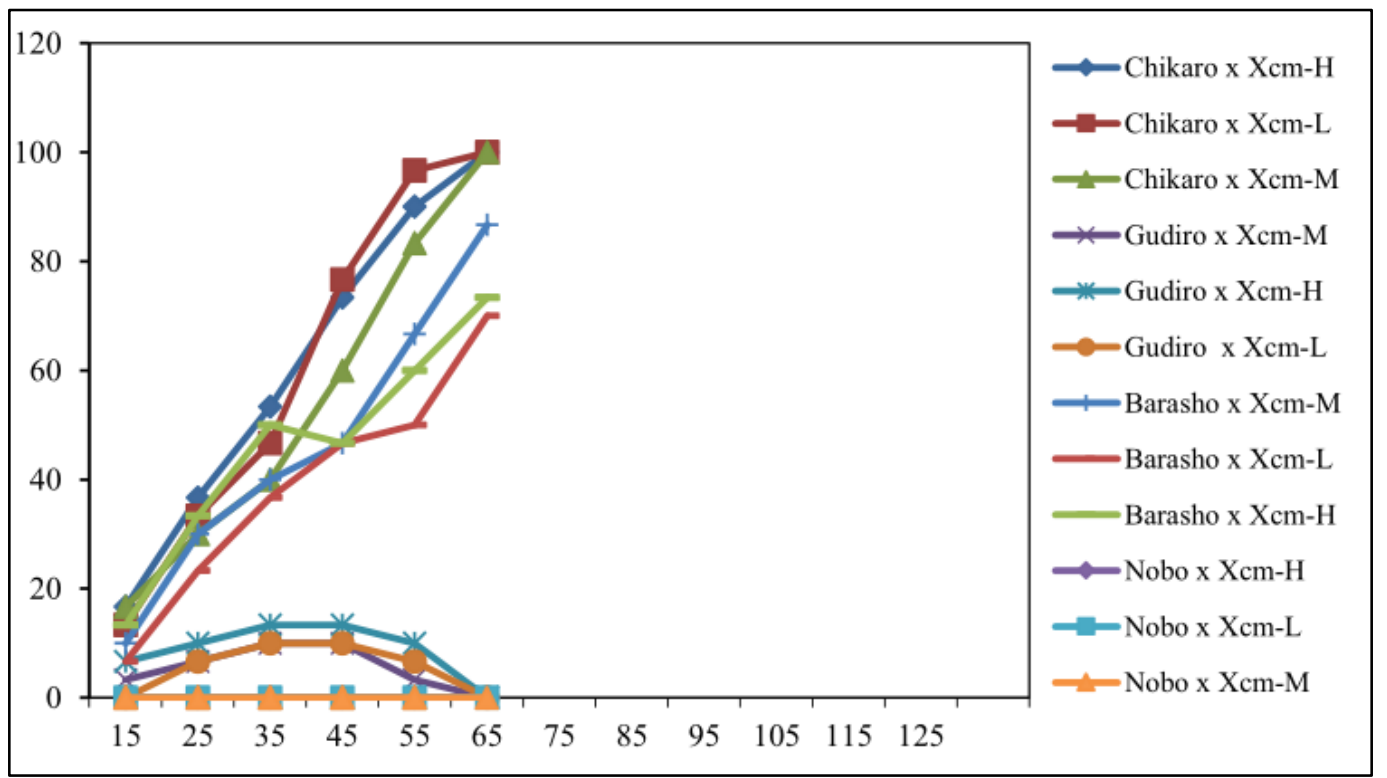

Figure 2. Enset bacterial wilt (Xanthomonas campestris pv. musacearum) disease progress curves as affected by enset clone $\mathrm{x}$ isolate interaction under screen house conditions in southwestern Ethiopia

Source: Haile et al., (2020)

\subsubsection{Selections of Drought Resistance Enset Clones through Conventional Breeding Methods}

The study was conducted in Agro-Ecological Zones of Hadiya, Southern Ethiopia Diversity and Resilient Varieties of Enset for Climate Change Adaptation (Table 3) (Nurebo, 2017). Among the identified 55 landraces, some landraces like Ginbo, Gishira, Disho, and Siskella were assessed as resilient varieties (Table 4). In line with this, many studies have used a variety of (Vernacular names) to identify on-farm diversity with the crop species that can farmers can recognized as diversity (Hajjar et al., 2008). Some varieties of enset showed similar with the result indigenous production methods and farmer-based biodiversity in major enset-growing regions of southern Ethiopia (Tsegaye and Struik, 2002). The resilient and vulnerable varieties were reported by more than $27 \%$ and $10 \%$ respectively are shown. Under stress conditions, the resilient varieties of enset were preferred by many farmers over the vulnerable varieties. This might be because of the drought resistance, productive characteristics of varieties, and adaptability to different agro-ecological zones (Nurebo, 2017). 
Table 3. Frequency of enset landraces in different agro-ecological zones of Hadiya zone

\begin{tabular}{llllllllll}
\hline N o & $\begin{array}{l}\text { Vernaculaar } \\
\text { name }\end{array}$ & Dega & w/dega & $\begin{array}{l}\text { Dry } \\
\text { w/dega }\end{array}$ & $\begin{array}{l}\text { N o } \\
\text { nernaculaar }\end{array}$ & Dega & w/dega & $\begin{array}{l}\text { Dry } \\
\text { w/dega }\end{array}$ \\
\hline 1 & Agade & 30 & 35 & 5 & 31 & Mekel wesa & 15 & 13 & 3 \\
2 & Zobira & 19 & 21 & 6 & 32 & Qashqeshiya & 13 & 10 & 0 \\
3 & Gishira & 25 & 33 & 10 & 33 & Hinba & 10 & 9 & 0 \\
4 & Qiniwara & 29 & 31 & 0 & 34 & Geriye & 13 & 17 & 2 \\
5 & Orada & 25 & 28 & 0 & 35 & Dirbo & 11 & 21 & 0 \\
6 & Tegadada & 0 & 15 & 0 & 36 & Lechee & 13 & 21 & 0 \\
7 & Xorora & 33 & 35 & 8 & 37 & Quina & 15 & 19 & 1 \\
8 & Separa & 30 & 36 & 3 & 38 & Abat merza & 17 & 10 & 0 \\
9 & Hiywona & 29 & 34 & 5 & 39 & Bekucho & 10 & 9 & 1 \\
10 & Moche & 35 & 29 & 0 & 40 & Shatadena & 7 & 17 & 0 \\
11 & Keseta & 19 & 20 & 1 & 41 & Mesmesicho & 21 & 12 & 0 \\
12 & Disho & 33 & 30 & 7 & 42 & Merza & 20 & 20 & 0 \\
13 & Ginbo & 31 & 37 & 5 & 43 & Amonda & 10 & 13 & 0 \\
14 & Astera & 21 & 26 & 2 & 44 & Sokido & 13 & 17 & 0 \\
15 & Bedade & 18 & 24 & 0 & 45 & Manduluka & 10 & 20 & 0 \\
16 & Shirafira & 20 & 0 & 0 & 46 & Menere & 11 & 23 & 0 \\
17 & Shate & 19 & 5 & 0 & 47 & Kekara & 5 & 7 & 0 \\
18 & Siskella & 25 & 35 & 6 & 48 & Bokessa & 7 & 13 & 0 \\
19 & Unjema & 24 & 34 & 5 & 49 & Bosora & 14 & 19 & 0 \\
20 & Ado'o & 20 & 0 & 0 & 50 & Wocereda & 18 & 21 & 3 \\
21 & Uskurusa & 19 & 27 & 0 & 51 & Mushawessa & 5 & 11 & 0 \\
22 & Benja & 23 & 29 & 2 & 52 & Lendere & 9 & 13 & 0 \\
23 & Tabute & 27 & 21 & 0 & 53 & Buchame & 3 & 7 & 0 \\
24 & Gozoda & 30 & 33 & 0 & 54 & Shetatena & 0 & 5 & 0 \\
25 & Hinuwa & 31 & 35 & 1 & 55 & Jajer iqee & 0 & 7 & 0 \\
26 & Kombotira & 19 & 29 & 0 & & & & & \\
27 & Woshameda & 21 & 25 & 0 & & & & & \\
28 & Oniya & 29 & 22 & 3 & & & & & \\
29 & Kd. Awnoda & 21 & 23 & 0 & & & & \\
30 & Ka. Awnoda & 25 & 27 & 0 & & & & \\
\hline
\end{tabular}

Source: (Nurebo, 2017).

Table 4. Resilient and vulnerable varieties of enset according to local farmers account (N70)

Source: (Nurebo, 2017)

\begin{tabular}{lllllll}
\hline No & Resilient clones & N & \%response & Vulnerable clones & N & \% response \\
\hline 1 & Ginbo & 30 & 42.85 & Xorora & 20 & 28.56 \\
2 & Gishira & 20 & 28.56 & Agade & 11 & 15.71 \\
3 & Disho & 20 & 28.56 & Beneja & 8 & 11.42 \\
4 & Siskella & 19 & 27.14 & Zobira & 7 & 10 \\
\hline
\end{tabular}

\subsubsection{Variability and Diversity Study of Enset through Classical Plant Breeding Methods}

Besides conventional, some experiments were done to know the variation in genetics in populations of enset land-races. The leaf samples of 71 enset were collected from Kefficho and Essera of south-west areas. Inter simple sequence repeats (ISSRs) were applied to assess their genetic diversity both between and within population using ISSR primers 834 and 826 . A total of 26 clear and reproducible bands were amplified from the two primers. All sample result indicated that clones from Kefficho were more diversified than those from Essera. Farther more; the portioning of Shannon diversity index showed that the major variations were observed within the population than between the two populations. All parameters of diversity confirmed the existence high diversity in genes within the populations. Therefore, the ISSR markers successfully applied for assessment genetic diversity assessment enset crop species (Tobiaw and Bekele, 2011). Even though it's potential in genetic and genomic studies; its support in breeding programs \& conservation efforts has been very limited. In the 
future, the molecular tool methods will improve the current conventional approaches methods. A research report indicated that the development of the first set of SSR markers from Enset, the way of cross transferability to Musa spp., and their application in genetic diversity, relationship, and structure assessments in wild and cultivated Enset germplasm. The SSR markers specifically to E. ventricosum were developed through pyro sequencing of an enriched genomic library. Primer pairs were designed for 217 microsatellites with a repeat size of $>20 \mathrm{bp}$ from 900 candidates. Primers were validated in parallel by in silico and in vitro PCR approaches. A total of 67 primer pairs were successfully amplified specific loci and 59 showed polymorphisms. Subsets of 34 polymorphic SSR markers were used to study 70 both wild and cultivated enset accessions. A large number of alleles were detected and the AMOVA revealed that intra-population allelic variations contributed more genetic diversity than inter-population variations. In this study, the cluster pattern was not associated with the geographical regions where this crop is grown. The results re-affirm the long tradition of extensive seed-sucker exchange between Enset producing in Southern Ethiopia.

Table 5. Summary of pyrosequencing data and number of identified di-tri and tetranucleotide SSR loci

\begin{tabular}{ll}
\hline Category & Numbers \\
\hline Total number of reads & 9,483 \\
Total number of base-pairs & $1.9 \mathrm{Mbp}$ \\
Number of quality reads & 8,649 \\
Average length quality reads & $214 \mathrm{bp}$ \\
Reads containing di- tri- and tetra-nucleotide SSR motifs with a size of $>20$ bp & 840 \\
Sequence reads with SSR flanking region & 215 \\
SSR loci identified for primer-pair design & 217 \\
Perfect motif types in the identified loci & 208 \\
Di nucleotide motifs & 192 \\
Tri nucleotide motifs & 14 \\
Tetra nucleotide motifs & 2 \\
Compound motif types in the identified loci & 9 \\
\hline
\end{tabular}

Source: (Olango et al., 2014)

\section{Summary and Conclusions}

Enset is widely cultivated in Ethiopia and is a traditional staple food crop for over 20 million peoples in the South and South-west parts of Ethiopia. It bears flowers which resemble bananas which developed into fruit and seed. It bears usually $15-25$ very hard, black seeds per fruit. It is also traditionally propagated by vegetative. Currently the request for new cultivars and traits including tolerance to diseases, environmental constraints like drought and frost is at high demand. As a result, it should be improved by conventional breeding through seeds and selection. Attempts have been done conventionally and classically for maintenance, conservation, developing varieties, and diversity or variability study of a crop. Areka agricultural research center collected a total of 623 Enset germplasm from 12 main Enset growing areas of Ethiopia and conserved in ex-situ at Areka SNNP. About 1,145 seeds of Enset were collected and stored at this millennium gene bank which is a world conservatory Kew's Millennium Seed Bank. Seedlings and specimens are held in Tropical Nursery at the garden of Cambridge Cottage and the Orange Room at Wakehurst. For selection purpose, about 400 Enset accessions were collected from the main Enset growing zone of the SNNP region. The accessions were evaluated, characterized, and maintained by Areka ARC. From these, 9 promising accessions were verified on the station of 5 different agricultural research centers having different agro-ecology and on-farm of 6 farmers and resulted in the release of 6 varieties of Enset as early set varieties (Yanbulle, Geweda, Endale) and late set varieties(Kelisa, Zerita, Mesena) which were the first in Ethiopia as well as in the world.

\section{References}

Assefa, A. S., \& Fitamo, D. (2016). Diversity of enset landraces (Ensete ventricosum (Welw) Cheesman) in Aleta Chuko District, Sidama Zone, South Nation Nationality People, and Regional State, Ethiopia. Journal of Plant Sciences, 4(1), 1-7.

Beyene, T. M. (2013). Morpho-agronomical characterization of taro (Colocasia esculenta) accessions in Ethiopia. Plant, 1(1), 1-9. https://doi.org/10.11648/j.plant.20130101.11

Birmeta, G., Nybom, H., \& Bekele, E. (2004.) The distinction between wild and cultivated enset (Ensete ventricosum) gene pools in Ethiopia using RAPD markers. Hereditas, 140(2), 139-148. 
https://doi.org/10.1111/j.1601-5223.2004.01792.x

Board of Trustees of the Royal Botanic Gardens, Kew. (2016). Cool tropical plants. Retrieved from http://www.cooltropicalplants.com/Abyssinian-banana.html

Haile, B., Finca, C., Terefe, H., Chala, A., \& Hussen, S. (2020). Evaluation of enset (Ensete ventricosum) clones for resistance reaction against pathogenic Xanthomonas campestris pv. Musacearum isolates from Southwestern Ethiopia. Cogent Food \& Agriculture, 6(1), 1773094. https://doi.org/10.1080/23311932.2020.1773094

Hajjar, R., Jarvis, D. I., \& Gemmill-Herren, B. (2008). The utility of crop genetic diversity in maintaining ecosystem services. Agriculture, Ecosystems \& Environment, 123(4), 261-270. https://doi.org/10.1016/j.agee.2007.08.003

Hunduma, T., Sadessa, K., Hilu, E., \& Oli, M. (2015). Evaluation of enset clones resistance against enset bacterial wilt disease (Xanthomonas campestris pv. musacearum). Journal of Veterinary Science and Technology, 6(3), 1-7.

Jarvis, D. I., Brown, A. H., Cuong, P. H., Collado-Panduro, L., Latournerie-Moreno, L., ... Hue, N. T. N. (2008). A global perspective of the richness and evenness of traditional crop-variety diversity maintained by farming communities. Proceedings of the National Academy of Sciences, 105(14), 5326-5331. https://doi.org/10.1073/pnas.0800607105

Karlsson, L. M., Dalbato, A. L., \& Tamado, T. (2011). Seed morphology and fresh seed germination of "false banana", Ensete ventricosum, (Musaceae). Informativo Abrates, 21, 132.

Karlsson, L. M., Tamado, T., Dalbato, A. L., \& Mikias, Y. (2013). Early growth and development of Ensete ventricosum (Musaceae) seedlings. Journal of Plant Sciences, 1(1), 11-17.

Negash, A. (2001). Diversity and Conservation of Enset (Ensete Ventricosum Welw.Cheesman) and Its Relation to Household Food and Livelihood Security in Southwestern Ethiopia. Ph.D. thesis Wageningen University and Research Centre, The Netherlands.

Nurebo, C. T. (2017). Diversity and resilient varieties of enset for climate change adaptation: the case of different agro-ecological zones of Hadiya, southern Ethiopia. Journal of Earth Science \& Climatic Change, 8(5). https://doi.org/10.4172/2329-6542.1000402

Olango, T. M., Tesfaye, B., Catellani, M., \& Pè, M. E. (2014). Indigenous knowledge, use, and on-farm management of enset (Ensete ventricosum (Welw.) Cheesman) diversity in Wolaita, Southern Ethiopia. Journal of ethnobiology and ethnomedicine, 10(1), 1-18. https://doi.org/10.1186/1746-4269-10-41

Semman, N., Garedew, W., \& Mulualem, T. (2017). On-Farm Based Enset Diversity Study and its Agronomic Practices in Sheka Zone Southwestern Ethiopia.

Tesfaye, B., \& Ludders, P. (2003). Diversity and distribution patterns of enset landraces in Sidama, Southern Ethiopia. Genetic Resources and Crop Evolution, 50(4), 359-371. https://doi.org/10.1023/A:1023918919227

Tobiaw, D. C., \& Bekele, E. (2011). Analysis of genetic diversity among cultivated enset (Ensete ventricosum) populations from Essera and Kefficho, southwestern part of Ethiopia using inter simple sequence repeats (ISSRs) marker. African Journal of Biotechnology, 10(70), 15697-15709. https://doi.org/10.5897/AJB11.885

Tsegaye, A., \& Struik, P. C.(2002). Analysis of enset (Ensete ventricosum) indigenous production methods and farm-based biodiversity in major enset-growing regions of southern Ethiopia. Experimental Agriculture, 38(3), 291-315. https://doi.org/10.1017/S0014479702003046

Tsegaye, A. (2002). On indigenous production, genetic diversity, and crop ecology of enset (Ensete ventricosum (Welw.) Cheesman). Ph.D. Thesis, Wageningen University, The Netherlands. p. 198.

Wolde, M., Ayalew, A., \& Chala, A. (2016). Assessment of bacterial wilt (Xanthomonas campestris pv. musacearum) of enset in southern Ethiopia. AJAR. 11(19), 1724-1733. https://doi.org/10.5897/AJAR2015.9959

Yemataw, Z., Mohamed, H., Diro, M., Addis, T., \& Blomme, G. (2012). Genetic variability, interrelationships, and path analysis in Enset (Ensete ventricosum) cultivars. Afri. Jour. Plant. Sci. Biotech, 6(1), 21-25

Yemataw, Z., Mohamed, H., Diro, M, Addis.T., \& Blomme, G. (2014b). Ethnic-based diversity and distribution 
of Enset (Enset ventricosum) cultivars in southern Ethiopia. Journal of Ecology and the Natural Environment, 6(7), 244-251.

Yemataw, Z., Tesfaye, K., Taddese, T., Dejene, T., Muzemil, S., Shashego, Z., \& Ambachew, D. (2016). Genetic variation for corm yield and other traits in Ethiopian enset (Ensete ventricosum (Welw.) Cheesman). Journal of Plant Breeding and Crop Science, 8(9), 150-156. https://doi.org/10.5897/JPBCS2015.0552

Yeshtila, M., Yemataw, Z., Muzemil, S., Ayalew, A., Negash, F., Michael, K., ... Welde, M. G. (2021). Registration of enset (Enset ventricosum (Welw.) Cheesman) varieties Yanbulle, Gewada, Endale, Kelisa, Zerita, and Mesena. Ethiopia Journal of Agricultural Science.

Zeberga, A., Yemataw, Z., Sinebo, W., \& Musemil, S. (2014). On-farm cultivar diversity of enset (Ensete ventricosum W.) in Southern Ethiopia. J Agric Dev, 4(1), 63-85

Zerfu, A., Gebre, S. L., Berecha, G., \& Getahun, K. (2018). Assessment of spatial distribution of enset plant diversity and enset bacteria wilt using geostatistical techniques in Yem special district, Southern Ethiopia. Environmental Systems Research, 7(1), 1-13. https://doi.org/10.1186/s40068-018-0126-9

\section{Copyrights}

Copyright for this article is retained by the author(s), with first publication rights granted to the journal.

This is an open-access article distributed under the terms and conditions of the Creative Commons Attribution license (http://creativecommons.org/licenses/by/4.0/). 